\title{
Potentials of Pesticidal Plants in Enhancing Diversity of Pollinators in Cropped Fields
}

\author{
Juliana Godifrey*, Ernest R. Mbega, Patrick A. Ndakidemi \\ Department of Sustainable Agriculture and Biodiversity Ecosystems Management School of Life Science and Bio-Engineering, \\ The Nelson Mandela African Institution of Science and Technology (NM-AIST), Arusha, Tanzania \\ Email: julianashikoshi@gmail.com
}

How to cite this paper: Godifrey, J., Mbega, E.R. and Ndakidemi, P.A. (2018) Potentials of Pesticidal Plants in Enhancing Diversity of Pollinators in Cropped Fields. American Journal of Plant Sciences, 9, 2659-2675.

https://doi.org/10.4236/ajps.2018.913193

Received: September 25, 2018

Accepted: December 18, 2018

Published: December 21, 2018

Copyright $\odot 2018$ by authors and Scientific Research Publishing Inc. This work is licensed under the Creative Commons Attribution International License (CC BY 4.0).

http://creativecommons.org/licenses/by/4.0/

\begin{abstract}
Declines in populations of pollinators in agricultural based landscapes have raised a concern, which could be associated with various factors such as intensive farming systems like monocropping and the use of non-selective synthetic pesticides. Such practices are likely to remove beneficial non-crop plants around or nearby the cropped fields. This may in turn result into losses of pollinators due to loss of the natural habitats for insects therefore, interfering the interaction between beneficial insects and flowering crop plants. Initiatives to restore friendly habitats for pollinators require multidisciplinary approaches. One of these could be the use of pesticidal flowering plants as part of field margin plants with the aim of encouraging the population of pollinators whilst reducing the number of pests. Farmers should be fully engaged in the efforts of creating conducive environments to pollinators and be well equipped with the knowledge of proper habitats management strategies in agricultural fields. Developing appropriate conservation strategies to combat decline of pollinators is of high importance and thus there is a need to evaluate management practices, which potentially favour the populations of pollinators. Therefore, this review aims at unravelling available evidences on habitats manipulation options through provision of flowering plants along the field margins that have shown to increase plant biodiversity surrounding the cropped fields. It also summarizes the options for increasing plant biodiversity, which have improved habitats for the pollinating insects and beneficially boosting pollination services in agro-ecosystems.
\end{abstract}

\section{Keywords}

Beneficial Insects, Cropping Options, Plant-Insects Interaction, Pesticidal Plants, Pollinators

\section{Introduction}

Some non-crop plants have a significant role to crop pollinators and other 
flower visitors and can be useful in making margins for flower-rich crops to encourage populations of beneficial insects [1]. Marshal et al. (2003) [2] indicated that some weeds are potential for the survival of beneficial insects in agricultural systems. For this case, introducing some specific weeds in agricultural fields has been indicated to boost floral resources to beneficial insects as well as providing nests and nesting materials for refuges [2]. In addition, retaining hedge-rows and insectary flowering plants in agro-ecosystems and leaving uncultivated lands around the crop fields help in provision of shelters, micro-climates and resources for pollinators and eventually increase the diversity of beneficial insects relative to monocropping [3]. It is well known that nectar or pollen feeding is vital for the reproductive success of many insect predators and parasitoids [4]. However, shortage of pollinators and the services they offer to the environments have increased for a long period due to habitat loss and degradation, as well as the increased use of synthetic pesticides [5] [6].

Monoculture cropping practices are reported to be associated with decline in the population of pollinators in different parts of the world [7]. Nevertheless, the removal of weeds around the cropped fields decreases the floral diversity as well as the foraging and nesting sites for wild species of insects. This results into reduction in diversity of pollinating insects, which in turn leads to decline in populations of pollinators [8]. Therefore, management strategies which focus on restoring and conserving diversity of beneficial plants such as the use of pesticidal plants in the cropped fields or around the fields are important. However, in facilitating diversity of plants in cropped field margins, appropriate manipulation strategies should be employed to avoid resource competition with the crop plants. Steffan-Dewenter et al. (2005) [9] indicated that specific plants attracted different groups of insects and therefore, in habitats manipulation, it is critical to select flowering plants while targeting a specific insect (Table 1). Insects pollinators are attracted to flowers by various characteristics including floral morphology, scenting odour, petal colour, taste of nectar, and texture of pollen [10] [11]. Considering these characteristics, pesticidal plants which are commonly grown within agro-ecosystems can potentially be utilized as important floral resources. Therefore, the inclusion of flowering pesticidal plants as part of cropped field margins deemed useful habitats to pollinators while providing additional benefits as biological pest control. It is under these explanations that this review explores the potentials of including pesticidal plants along field margins so as to enhance diversity of pollinators in cropped fields.

\section{Importance of including Pesticidal Plants in Margins of Cropped Fields}

Flowering plants favour existence of beneficial insect species in the fields resulting into optimized and sustainable crop productivity. Different non-crop plants have been reported to attract beneficial insects in crop ecosystems due to ecological relationships between the plant resources and insect biology [12]. 
Table 1. Common plant species attracting pollinators.

\begin{tabular}{|c|c|c|}
\hline Plant specie & Visiting Pollinators & Reference \\
\hline $\begin{array}{l}\text { Trifolium pratense, Ballota nigra, Lamium album, } \\
\text { Teucrium scorodonia, Centaurea nigra }\end{array}$ & Bumble bee (Bombus spp) & Carvell (2006) [16] \\
\hline $\begin{array}{l}\text { Trifolium hybridum, Cirsium vulgare, Onobrychis } \\
\text { viciifolia, Lotus corniculatus, Leucanthemum vulgare } \\
\text { and Achillea millefolium }\end{array}$ & Most hymenopteran & Kassina et al. (2006) [15] \\
\hline $\begin{array}{l}\text { Fagopyrum sagittatum, Trifolium hybridum and } \\
\text { Agastache foeniculum }\end{array}$ & Cresson (Microplitis croceipes) & [21] \\
\hline $\begin{array}{l}\text { Sium suave (Apiaceae) and Solidago Canadensis } \\
\text { (Asteraceae) }\end{array}$ & $\begin{array}{l}\text { Most hymenopteran including Wasps species } \\
\text { Myzinum quinquecinctum (tiphiid) and } \\
\text { Scolia bicincta (scoliid) }\end{array}$ & {$[24][25]$} \\
\hline $\begin{array}{l}\text { Coriander, phacelia, alyssum, fennel, buckwheat, } \\
\text { mustard }\end{array}$ & Hoverflies & [10] \\
\hline $\begin{array}{l}\text { Allium cepa, Daucus carota, Coriandrum sativum, } \\
\text { Cirsium arvense, Launaea procumbens, } \\
\text { Ranunculus muricatus and Prosopis juliflora }\end{array}$ & Hoverflies & [26] \\
\hline $\begin{array}{l}\text { Glebionis segetum Corn marigold, } \\
\text { Coriandrum sativum Coriander, Foeniculum } \\
\text { vulgare Fennel, Phacelia tanacetifolia (Phacelia) }\end{array}$ & Wasps and Hoverflies & [27] \\
\hline $\begin{array}{l}\text { fennel, cosmos hypericum, yarrow, lavender, bishop's } \\
\text { weed, petunia, chamomile }\end{array}$ & Hoverflies & [28] \\
\hline $\begin{array}{l}\text { Tagetes erecta, Foeniculum vulgare, Ocimum, } \\
\text { Ziziphora interrupta }\end{array}$ & Syrphidae, Anthocoridae and Coccinellidae & [20] \\
\hline $\begin{array}{l}\text { Aster pilosus (Asteracea) and Heracleum maximum, } \\
\text { Pastinaca sativa, Cicuta maculata (Apiaceae) }\end{array}$ & Syrphidae and tachnid flies & [29] \\
\hline $\begin{array}{l}\text { Hyptis suaveolens, Tagets minuta, Ageratum cinyzoides, } \\
\text { Ocimum suave, Bidens pilosa }\end{array}$ & Stingless bee and butter flies & [17] \\
\hline
\end{tabular}

Understanding of the biology and ecology of different crop and non-crop plants is relevant in designing valuable vegetative barriers in cropped fields [13]. Diversity of field margin plants across the cropping seasons can have a major influence on insect dynamics [14]. Kasina et al. (2006) [15] confirmed the diversity of beneficial arthropods to be enhanced by the field margin plants.

Different species of flowering plants with pesticidal properties have been reported to show promising results in attracting pollinators when planted as field margin plants. These plants include Trifolium pratense, Ballota nigra, Centaurea nigra, Teucrium scorodonia, Lamium album, Trifolium hybridum, Cirsium vulgare, Onobrychis viciifolia, Lotus corniculatus, Leucanthemum vulgare, and Achillea millefolium [16]. Karani et al. (2017) [17] found that Hyptis suaveolens, Osimum suave, Bidens pilosa, Tagetes minuta, and Ageratum conyzoides influenced the population of pollinators while reducing the number of pests in cultivated fields.

Pollinators such as parasitic wasps perform their full role of biological control and pollination when provided with essential sugar resources for their survival [18]. Wasps are attracted by volatiles that are produced by plant tissues of pesticidal plants (Brodmann et al. 2008) [19]. The contribution of pesticidal plants that produce secondary metabolites in form of volatile organic compounds to 
attract pollinating insects is widely documented [16] [17] [18] [19] [20]. Therefore, if pesticidal plants are well utilized as field margin plants they are expected to attract diverse species of pollinators due to their aroma characteristics.

Nafziger and Fadamiro (2011) [21] investigated the suitability of buckwheat (Fagopyrum sagittatum), sweet alyssum (Lobularia maritima) and licorice mint (Agastache foeniculum) as nectar sources for Cresson wasp (Microplitis croceipes) a potential parasitoid of some caterpillar pests and a pollinator. Their study found that the longevity of adult Microplitis croceipes was enhanced by buckwheat and licorice mint but females outperformed the males. They attributed these observations with the amount of energy needed for the host location and oviposition by females.

The use of pesticidal plants as artificial pesticide replacers has also been reported [22]. The pesticidal plants also provide ecosystem services like pollination and biological pest control in agricultural fields [23]. Tooker and Hanks (2014) [24] identified several species of hymenopteran which visited the pesticidal flowering plant hosts. The host plants visited were Sium suave (Apiaceae), Solidago canadensis (Asteraceae) and the wasp's species were Myzinumquin quecinctum (tiphiid) and Scolia bicincta (scoliid). Wasps have also been indicated to visit Apiaceae plants due to exposed anthers and nectar since mouthparts of these insects are not adopted specifically for extracting floral resources [25].

The importance of flowering plants as both attractant to natural enemies and pollinators is widely investigated [10] [26] [27] [28] [29]. Some plant species were potential floral resource to hoverflies [10] an effective pollinator and a natural enemy of aphids [30]. Martini et al. (2014) [28] reported the importance of plant species such as fennel, cosmos hypericum, yarrow, lavender, bishop's weed, petunia and chamomilein in attracting hoverflies species. Sajjad and Saeed (2010) [26] reported Allium cepa, Daucus carota, Coriandrum sativum, Cirsium arvense, Launaea procumbens, Ranunculus muricatus, and Prosopis juliflora to be the potential attractants of syrphid species under natural conditions.

Sievwright et al. (2006) [27] investigated the attractiveness of Coriandrum sativum Coriander, Glebionis segetum Corn marigold, Foeniculum vulgarum (Fennel) and Phacelia tanacetifolia (Phacelia) on lacewings, parasitic wasps, ladybirds and hoverflies, as key natural enemies of pests and pollinators in agricultural fields. Saidov and Douglas (2008) [20] studied the key natural enemies and pollinators including Syrphidae, Anthocoridae and Coccinellidae using pesticidal plants such as Tagetes erecta, Foeniculum vulgare, Ocimum basilicum and Ziziphora interrupta which showed promising performance. Tooker et al. (2014) [29] studied the plant species preferred by syrphid and tachinid flies and found that most syrphid and tachinid flies visited Aster pilosus (Asteracea), Heracleum maximum, Pastinaca sativa and Cicutam aculata (Apiaceae). Therefore, inclusion of strips of pesticidal plants as a field margin could offer a multiple purpose in reducing number of pests whilst favouring beneficial insects most of them being pollinators. Table 1 shows various studies reported on usage of pesticidal plants in attracting pollinators. 


\section{Role of Pollinators in Crop Productivity}

Pollination services are referred to as the transfer of pollen grains from the floral anthers to the floral stigma of a different plant (cross-pollination) or the same plant (self-pollination) [31]. Kron et al. (2001) [32] reported that pollinators take pollen from anthers and deliver them to the stigma through foraging. Pollination depends on the plant-animal association, whereby both plants and animals benefit from the service.

There is an interaction between floral signals and the senses of the pollinators [33]. Floral signals are delivered by the synthesized volatile organic compounds, and some of them are derivatives of fatty acids, some nitrogenous compounds, terpenoids and benzenoids [34]. Floral volatiles emitted by the plants have potential in attracting specific groups of pollinators, some being common to most plants while others differ from plant to plant. Due to this chemical prompt the pollinators such as honey in bees that can fly long distances in attraction of such floral resources [35] [36]. In addition, indicated that flowers provided amino acids and carbohydrates as sources of energy for reproduction, oviposition, development and survival of beneficial insects including the pollinators [37] [38]. Since, pesticidal plants produce these volatile compounds as secondary metabolites, if well maintained within the agricultural landscape they would be a good floral resource for pollinators.

Ecosystem services such as biological control of pests, pollination, soil formation and nutrient cycling are provided by pollinators and natural enemies in many agricultural fields [23]. Beneficial insects-mediated services such as pollination are essential for livelihoods improvement as they provide assurance of food security. Subsistence agriculture is the backbone of smallholder in most African countries and thus, pollination is the key and essential service for boosting the economies through cultivation of different crops and products [39] [40]. Studies have revealed that $75 \%$ of agricultural crops are insect pollinated, in which up to $87.5 \%$ of flowering plants in the tropics and temperature zones benefit from insect pollinators which are naturally found in the environment [41]. Bees are key pollinators of many crops and hence it is important to provide comfortable environment and resources such as nectar, pollen, places for overwintering for the insects for their sustainable ecosystem services [42] [43] [44]. Thus, pollinators require specific recognition in agro-ecological system because of their importance in pollination process in agriculture and natural ecosystems.

Generally, quality and yield of different crops are reported to increase when there is pollinators' involvement [45]. For instance, in self-pollinated crop like beans yield has been reported to increase by $5 \%$ in presence of insect pollinators [46]. Aouar-sadli et al. (2008) [47] investigated the pollination potential of wild bees (Eucera pulveracea), honey bees Apis mellifera and carpenter bees (Xylocopa violacea) in relation to seed production on the broad bean (Fabaceae). Their findings revealed that the wild bees made frequent visits to broad bean but the honey bees and the carpenter bee made several visits to forage. In a similar study, Barbir, (2015) [30] observed that the presence of bees increased yield in 
cross-pollinated coriander than in self-pollinated. Stein et al. (2017) [48] found that cross-pollination by honey bees and wild bees successfully improved the quality of cotton and sesame products.

Bischoff et al. (2013) [49] investigated the visits of Syrphid flies (Allograpta spp) and solitary bees (Hylaeus matamoko) on two New Zealand alpine herbs; Ourisiagla ndulosa and Wahlenbergia albomarginata and found that both pollinators had equal frequencies of visits to Ourisiagla ndulosa, while the solitary bee had more frequencies of visits to Wahlenbergia albomarginata. Insect pollinators have a lot to do with the reproduction potential of flowering plants regardless of the mode of reproduction of a particular crop plant. Thus, there is a continuous need of considering and investigating the relative attractiveness of the field margin plants to pollinators for sustainable crop production in agricultural systems.

In addition to optimized crop productivity, pollination enhances food security as well as genetic variation among crops, which lessens inbreeding depression and accelerates resistance to environmental changes [50] [51] [52]. Therefore, the knowledge on management techniques which attract different pollinators in the agricultural fields is an important way forward to enhanced agro-ecosystems for increased crop production.

\section{Roles of Selected Pesticidal Plants in Controlling Pests and Attracting Pollinators}

This review provides detailed explanations to three pesticidal plants namely Hyptis suaveolens, Ocimum suave and Dysphania ambrosioides as the representatives of the diverse flower producing pesticidal plants that could be used as field margin plants. These pesticidal plants are mostly used by farmers as plant protectants against insect pests and their occurrence is abundant in local settings [53] [54]. Considering the use of these plants in biological pest control and the association of pollinators with the volatile organic compounds produced by different plants, it deemed useful to include them as field margin plants to enhance the population of insect pollinators in cultivated fields. The odour characteristic of most pesticidal plants provides them with added advantage to be attracted by the senses of pollinators. In addition, among the selected plants $H$. suaveolens and $O$. suave are reported to have influence on attracting many stingless bees and butterflies in common bean intercrops [17]. However, based on farmers' field experience, $O$. suave fresh leaves are used by bee keepers in cleaning the beehives because of its ability to attract many honey bees. Despite the potential influence of these plants to pollinators, little is known on their potential role in attracting pollinators in agricultural fields.

\section{Hyptis suaveleons as a Beneficial Pesticidal Plant}

$H$. suaveolens belongs to the family Lamiaceae and has been traditionally used as a botanical pesticide in many developing countries due to its insecticidal and re- 
pellent properties against several field and storage insect pests [51] More than 400 species of the genus Hyptis are characterized by high aromatic and grow in tropical regions, mostly in Africa and America and it is not commonly found over $500 \mathrm{~m}$. The plant is normally restricted to places where soils have been intensely disturbed, and may be considered as a ruderal species [55]. H. suaveolens is found around villages, along roadsides, on-farmsteads and on bushes. Its oil constituents have been used in controlling stem borer in maize intercrop [56]. Chemical screening for the chemical constituent of its aqueous extracts revealed that the plant is rich in flavonoids and alkaloids (Figure 1). Other secondary compounds include tannins and phenols [57]. When tested against Fusarium oxysporum in Gladiolus corms, it significantly reduced the pathogen population during storage [58]. In addition, an extract from the fresh leaves were reported to have larvicidal and repellence properties against the Asian tiger mosquito, Aedes albopictus Skuse (Diptera: Culicidae).

Ofuya (2010) [60] evaluated the efficacy of the H. suaveolens extracts on storage pests, namely Sitophilus oryzae, Sitophilus zeamais and Callosobruchus maculatus. The results of this study revealed that methanolic extract of the plant at $100 \%$ concentration was able to cause mortality of all exposed insect pests after 5 seconds. Chi and Apiah (2012) [61] tested the toxicity and feeding deterrent using $H$. suaveolens ethanol, distilled water, chloroform, petroleum, ether and methanol extracts on cowpea weevils, Callosobruchus maculatus. Their findings indicated that chloroform extracts at the concentrations of 250 and $500 \mu \mathrm{g} / \mathrm{ml}$ showed $100 \%$ deterrent effect to the weevils whereas, the chloroform extract at the concentration of $125 \mu \mathrm{g} / \mathrm{ml}$ showed the least deterrent effect. When compared, chloroform extracts caused the highest mortality at an average of $41 \%$ whereas ethanol extract had the lowest average mortality of $29 \%$. Contrarily, the flowers of $H$. suaveolens have been reported to provide pollen and nectar to bees and butterfly for its pollination process by hovering around the flowers and touching the carinal-corolla with their proboscis [62]. However, the potential role of this plant in attracting populations of pollinators in agriculture production is underestimated in most parts of the world where similar studies have been conducted [62] [63]. Thus, further research needs to be done to investigate the importance of these plants in attracting pollinators to increase crop productivity.

\section{Ocimum suave as a Beneficial Pesticidal Plant}

Ocimum suave is also known as Wild Basil and it belongs to the family Lamiaceae or Labiatae. Lamiaceae family have been used since early times because of its medicinal properties and many of these species are distributed in Mediterranean and tropical countries across the world [64]. The three main centres of Ocimum diversity has been reported as tropical and subtropical parts of Africa and America and tropical Asia [65]. The phytochemical analysis (Figure 2) has identified eugenol as the major component of $O$. suave essential oil [66] [67]. 
<smiles>O=c1cc(-c2ccccc2)oc2ccccc12</smiles>

i. Flavone<smiles>O=c1c(-c2ccccc2)coc2ccccc12</smiles>

ii. Isoflavone

(a)<smiles>NCC(=O)O</smiles>

(b)

Figure 1. Chemical structures of some Flavonoid and Alkaloid compounds [59]. (a) Flavonoid compounds; (b) Alkaloid compound.

Several studies have been conducted on the toxicity of the leaf oil on important agricultural pests. Ojuanwuna et al. (2013) [69] tested the toxicity of the plant oil extracts on the bruchid (Callosobruchus maculatus), which is a cowpea weevil, and a major problem in storage of cowpea seeds in the tropics. Their study revealed that the crude oil extracts had a potential insecticidal activity on the weevil and the mortality increased with extract concentration from 0.02 to $0.08 \mathrm{mg} / 20 \mathrm{ml}$ of water. However, the period of exposure from 24 to $96 \mathrm{~h}$ was an important factor for the mortality of the insects. Obeng-Ofori and Reichmuth (1997) [70] investigated the toxicity of eugenol against four coleopteran species of stored-products, which are Sitophilus granarius, Sitophilus zeamais, Tribolium castaneum and Prostephanus truncates. Their study found that mortality effect on the beetles increased with extract dosage and exposure time. High mortality occurred on $S$. granarius, $S$. zeamais and $T$. castaneum at higher dose. The eugenol also significantly inhibited the development of eggs, larvae, and pupae and was highly repellent to the Coleopterans. Similar findings were obtained by Obeng-Ofori et al. (2000) [66] when investigating the effectiveness of essential oil of the Ocimum plant species namely $O$. kenyense, $O$. suave, and $O$. kilimandscharicum against storage pests $S$. zeamais and $P$. truncates. The essential oils from all species extracts indicated a dose-dependent mortality effect against the pests. The oils also resulted into inhibition of developments of the eggs, larva and pupa, oviposition by the adults, deterrence and the repellence. However, there is limited understanding of the role of $O$. suave plant in supporting beneficial insects (pollinators). Thus, future research should focus on $O$. suave to determine its potential role for promoting diversity of populations of pollinators. 


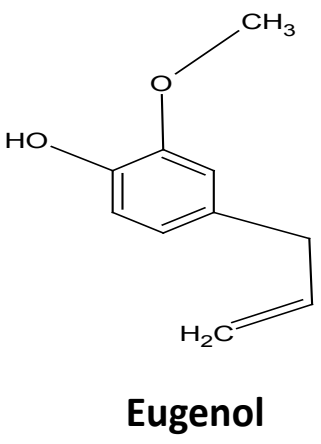

Figure 2. Chemical structure of Eugenol [68].

\section{Dysphania ambrosioides (Chenopodium ambrosioides) as a Beneficial Pesticidal Plant}

Dysphania ambrosioides belongs to Chenopodiaceae, a family of varieties of herbaceous weedy plants [71]. The genus Chenopodium comprises about 250 species [72] which most species are annuals, distributed in the Americas, Asia, and Europe. D. ambrosioides has been used for medicinal purposes mainly for treating intestinal parasites [73]. However, its use ranges from pharmaceutical purposes to pest control in agricultural fields [74]. Reported bioactive compounds of Dysphania ambrosioides essential oil includes, ascaridole, isoascaridole, $\alpha$-terpinene, Isoascaridolnene, 2-carinene and p-cymene [75] of which ascaridole is the major compound constituting $40 \%-70 \%$ of the total active compound present [76] (Figure 3).

The activities of the plant extracts and its essential oil against different agricultural pests have been studied. Vázquez-Covarrubias et al. (2015) [78] tested the effects of essential oils and the aqueous extracts of Chenopodiaceae plants including $D$. ambrosioides on the development and reproductive potential of Lepidopteran Copitarsia decolora. This is a serious pest of several plants including Brassicaceae species [79]. The results indicated that the essential oils of $D$. ambrosioides at $0.5 \%$ significantly reduced larval weight to $33 \%$ compared with the control $(\mathrm{F}=2.1, \mathrm{df}=5,328, \mathrm{p}>0.05)$. The essential oil also increased duration of the larval period at $0.1 \%$ concentration compared with the control by $20 \%(\mathrm{H}=60.9, \mathrm{df}=6,400, \mathrm{p} \leq 0.00)$, and this was the largest while all the essential oils at the concentration of $0.5 \%$ increased the duration of the larval period in relation to the control $(\mathrm{F}=74.917, \mathrm{df}=6,172, \mathrm{p}<0.001)$. It was further observed that the essential oils at a concentration of $0.5 \%$ significantly reduced fecundity by $88 \%(\mathrm{~F}=38.5, \mathrm{df}=6,74, \mathrm{p}<0.001)$ whereas $0.5 \%$ of aqueous extracts reduced the fecundity by $70 \%(\mathrm{~F}=14.4, \mathrm{df}=5,97, \mathrm{p}<0.001)$. Furthermore, $D$. ambrosioides essential oils significantly decreased survival time for Copitarsia decolora. At $0.5 \%$ concentration, the oils significantly reduced the number of fertile eggs by $93 \%(\mathrm{~F}=36.6, \mathrm{df}=6,74, \mathrm{p}<0.001)$ while at $75 \%$ caused significant largest reduction in fertility $(\mathrm{F}=13.4, \mathrm{df}=5,97, \mathrm{p}<0.001)$.

Insecticidal properties of a Chenopodium-based botanical effects on different pests including green peach aphid (Myzuspersicae) greenhouse whitefly 


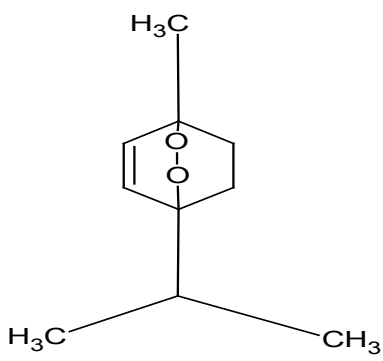

Figure 3. Chemical structure of Ascaridol [77].

(Trialeurodes vaporariorium), and flower thrips (Frankliniellaocci dentalis) are also reported. A mixture of UDA-245 (which was based on an essential oil extracts from $D$. ambrosioides had potential in controlling aphids, thrips and whiteflies compared with neem oil, insecticidal soap and endosulfan. Insecticidal soap exhibited high mortality of the parasitoid Encarsia formosa (Aphelinidae) than emulsifiable concentrate but UDA-245 was safer to the parasitoid [80].

Denloye et al. (2010) [81] investigated toxicity of Chenopodium ambrosioides powder extracts and essential oil against storage insect pests namely Callosobruchus maculatus (Bruchidae), S. zeamais (Curculionidae) and T. castaneum (Tenebrionidae). Their study found that Dysphania ambrosioides powder induced toxicity to $S$. zeamais compared with other test organisms. Ethanol extract and essential oils were more effective against Callosobruchus maculatus compared with other test organisms. Based on these explanations, there is limited scientific data on the use of this herb in attracting beneficial insects to promote crop pollination. Hence, it is crucial to undertake studies so as to generate data on the role of $D$. ambrosioides in enhancing populations of pollinators.

\section{Conclusion}

This review has demonstrated that ecosystem services such as pollination are interfered by habitat manipulation and landscape disturbance, which ultimately leads to disruption of the communities of plant pollinators. Agricultural intensification has led to reduction in floral resources, nesting places for pollinators and thus decreases pollinator abundance and diversity. This has created a need for appropriate habitat management practices such as the use of field margin plants as a mitigating strategy in reducing pollinator decline for crop production. For development of sustainable conservation practices and increasing productivity, it is important to understand and identify plants that play role in the maintenance of the pollinators' populations to improve the ecosystem services while boosting the biological pest control. In this case, various pesticidal plant species can be fully utilized to provide dual function within agro-ecosystem. To date, few studies have been done on the potentials of some native pesticidal plants in promoting the diversity of the agents of pollination. Therefore, further research is needed in identifying specific pesticidal plants species that potentially influence pollinators' population and the volatiles that enhance their visits. 
Again, studies on proper design of these plants are of high importance to avoid competition with crop plants. Among pesticidal plant species used, Hyptis suaveolens, Osimum suave and Dysphania ambrosioides have been fully utilized in the control of crop storage pests due to their secondary compounds that are responsible for insecticidal activities which are also likely to have influence in attraction of beneficial insects including pollinators. These plant species may therefore be important as resources in promoting the diversity of pollinators for increasing crop productivity.

\section{Acknowledgements}

We acknowledge the financial support received from the African Development Bank (AfDB) tenable at the Nelson Mandela African Institution of Science and Technology (NM-AIST). I also acknowledge University of Greenwich through McKnight Foundation Project for their support in writing this review paper as part of their Collaborative Crop Research Programme http://www.ccrp.org. We are also grateful to Dr. Benigni Alfred Temba of Sokoine University of Agriculture for his valuable comments during preparation of this review.

\section{Conflicts of Interest}

The authors declare no conflicts of interest regarding the publication of this paper.

\section{References}

[1] Gurr, G.M., Wratten, S.D., Tylianakis, J., Kean, J. and Keller, M. (2005) Providing Plant Foods for Natural Enemies in Farming Systems: Balancing Practicalities and Theory. In: Wäckers, F.L., van Rijn, P.C. and Bruin, J., Eds., Plant-Provided Food for Carnivorous Insects. A Protective Mutualism and Its Applications, Cambridge University Press, Cambridge, 326-347.

[2] Marshall, A.H., Abberton, M.T., Williams, T.A., Michaelson-Yeates, T.P.T. and Powell, H.G. (2003) Forage Quality of Trifolium repens L. $\times$ T. nigrescens Viv. hybrids. Grass and Forage Science, 58, 295-301.

https://doi.org/10.1046/j.1365-2494.2003.00381.x

[3] Dufour, R. (2000) Farmscaping to Enhance Biological Control. Appropriate Technology Transfer for Rural Areas. http://attra.ncat.org/attra-pub/PDF/farmscaping.pdf

[4] Wäckers, F.L. and van Rijn, P.C. (2005) Food for Protection: An Introduction. In: Wäckers, F.L., van Rijn, P.C. and Bruin, J., Eds., Plant-Provided Food for Carnivorous Insects. A Protective Mutualism and Its Applications, Cambridge University Press, Cambridge, 1-14.

[5] Allen-Wardell, G., Bernhardt, P., Bitner, R., Burquez, A., Buchmann, S., Cane, J., Cox, P.A., Dalton, V., Feinsinger, P., Ingram, M. and Inouye, D. (1998) The Potential Consequences of Pollinator Declines on the Conservation of Biodiversity and Stability of Food Crop Yields. Conservation Biology, 12, 8-17.

[6] Nicholls, C.I. and Altieri, M.A. (2013) Plant Biodiversity Enhances Bees and Other Insect Pollinators in Agroecosystems. A Review. Agronomy for Sustainable development, 33, 257-274. https://doi.org/10.1007/s13593-012-0092-y 
[7] Öckinger, E. and Smith, H.G. (2007) Semi-Natural Grasslands as Population Sources for Pollinating Insects in Agricultural Landscapes. Journal of applied ecology, 44, 50-59. https://doi.org/10.1111/j.1365-2664.2006.01250.x

[8] Steffan-Dewenter, I., Pott, S.G. and Packer, L. (2005) Pollinator Diversity and Crop Pollination Services Are at Risk. Trends in Ecology \& Evolution, 20, 651-652. https://doi.org/10.1016/j.tree.2005.09.004

[9] Rahat, S., Gurr, G.M., Wratten, S.D., Mo, J. and Neeson, R. (2005) Effect of Plant Nectars on Adult Longevity of the Stinkbug Parasitoid, Trissolcus basalis. International Journal of Pest Management, 51, 321-324. https://doi.org/10.1080/09670870500312778

[10] Colley, M.R. and Luna, J.M. (2000) Relative Attractiveness of Potential Beneficial Insectary Plants to Aphidophagous Hoverflies (Diptera: Syrphidae). Environmental Entomology, 29, 1054-1059. https://doi.org/10.1603/0046-225X-29.5.1054

[11] Fenster, C.B., Armbruster, W.S., Wilson, P., Dudash, M.R. and Thomson, J.D. (2004) Pollination Syndromes and Floral Specialization. Annual Review of Ecology, Evolution, and Systematics, 35, 375-403. https://doi.org/10.1146/annurev.ecolsys.34.011802.132347

[12] Van Emden, H. (1965) The Role of Uncultivated Land in the Biology of Crop Pests and Beneficial Insects. Scientific Horticulture, 17, 121-136.

[13] Molthan, J. and Ruppert, V. (1988) Significance of Flowering Wild Herbs in Boundary Strips and Fields for Flower-Visiting Beneficial Insects. Mitteilungen aus der Biologischen Bundesanstalt fuer Land-und Forstwirtschaft Berlin-Dahlem (Germa$n y, F R), 247,85-99$

[14] Altieri, M.A. and Letourneau, D.K. (1982) Vegetation Management and Biological Control in Agroecosystems. Crop Protection, 1, 405-430. https://doi.org/10.1016/0261-2194(82)90023-0

[15] Kasina, J., Nderitu, J., Nyamasyo, G., Olubayo, F., Watur, C., Obudho, E. and Yobera, A.D. (2006) Evaluation of Companion Crops for Thrips (Thysanoptera: Thripidae) Management on French Bean Phaseolus vulgaris (Fabaceae) International Journal of Tropical Insect Science, 26, 121-125. https://doi.org/10.1079/IJT2006105

[16] Carvell, C., Roy, D.B., Smart, S.M., Pywell, R.F., Preston, C.D. and Goulson, D. (2006) Declines in Forage Availability for Bumblebees at a National Scale. Biological Conservation, 132, 481-489. https://doi.org/10.1016/j.biocon.2006.05.008

[17] Karani, A. (2017) Effect of Intercropping Selected Pesticidal Plants with Common Bean on Aphids Infestation and Natural Enemies Abundance. A Dissertation Submitted in Partial Fulfillment of the Equirements for the Degree of Masters in Life Science of the Nelson Mandela African Institution of Science and Technology, 41-42.

[18] Wäckers, F.L. (2001) A Comparison of Nectar- and Honeydew Sugars with Respect to Their Utilization by the Hymenopteran Parasitoid Cotesia glomerata. Journal of Insect Physiology, 47, 1077-1084. https://doi.org/10.1016/S0022-1910(01)00088-9

[19] Brodmann, J., Twele, R., Francke, W., Hölzler, G., Zhang, Q.H. and Ayasse, M. (2008) Orchids Mimic Green-Leaf Volatiles to Attract Prey-Hunting Wasps for Pollination. Current Biology, 18, 740-744. https://doi.org/10.1016/j.cub.2008.04.040

[20] Saidov, N.S. and Douglas, L.A. (2008) Evaluation of Flowering Plants to Attract Natural Enemies in Tajikistan. Journal of Biological Sciences, 5, 19-28.

[21] Nafziger Jr., T.D. and Fadamiro, H.Y. (2011) Suitability of Some Farmscaping Plants as Nectar Sources for the Parasitoid Wasp, Microplitis croceipes (Hymenop- 
tera: Braconidae, Effects on Longevity and Body Nutrients. Biological Control, 56, 225-229. https://doi.org/10.1016/j.biocontrol.2010.11.005

[22] Mkindi, A.G., Mtei, K.M., Njau, K.N. and Ndakidemi, P.A. (2015) The Potential of Using Indigenous Pesticidal Plants for Insect Pest Control to Small Scale Farmers in Africa. American Journal of Plant Sciences, 6, 3164-3174.

https://doi.org/10.4236/ajps.2015.619308

[23] Ndakidemi, B., Mtei, K. and Ndakidemi, P.A. (2016) The Potential of Common Beneficial Insects and Strategies for Maintaining Them in Bean Fields of Sub Saharan Africa. American Journal of Plant Sciences, 7, 425-436. https://doi.org/10.4236/ajps.2016.73036

[24] Tooker, J.F. and Hanks, L.M. (2014) Flowering Plant Hosts of Adult Hymenopteran Parasitoids of Central Illinois. Annals of the Entomological Society of America, 93, 580-588. https://doi.org/10.1603/0013-8746(2000)093[0580:FPHOAH]2.0.CO;2

[25] Patt, J.M., Hamilton, G.C. and Lashomb, J.H. (1997) Foraging Success of Parasitoid Wasps on Flowers: Interplay of Insect Morphology, Floral Architecture and Searching Behavior. Entomologia Experimentalis et Applicata, 83, 21-30. https://doi.org/10.1046/j.1570-7458.1997.00153.x

[26] Sajjad, A. and Saeed, S. (2010) Floral Host Plant Range of Syrphid Flies (Syrphidae: Diptera) under Natural Conditions in Southern Punjab, Pakistan. Pakistan Journal of Botany, 42, 1187-1200.

[27] Sievwright, H.C., Sutton, G.L. and Rosenfeld, A. (2006) Plants for Predators-A Participatory Experiment. Aspects of Applied Biology, 79, 121-124.

[28] Martini, X., Pelz-Stelinski, K.S. and Stelinski, L.L. (2014) Plant Pathogen-Induced Volatiles Attract Parasitoids to Increase Parasitism of an Insect Vector. Frontiers in Ecology and Evolution, 2, 8. https://doi.org/10.3389/fevo.2014.00008

[29] Tooker, J.F., Hauser, M. and Hanks, L.M. (2014) Floral Host Plants of Syrphidae and Tachinidae (Diptera) of Central Illinois. Annals of the Entomological Society of America, 99, 96-112. https://doi.org/10.1603/0013-8746(2006)099[0096:FHPOSA]2.0.CO;2

[30] Barbir, J., Badenes-Pérez, F.R., Fernández-Quintanilla, C. and Dorado, J. (2015) Can Floral Field Margins Improve Pollination and Seed Production in Coriander Coriandrum sativum L. (A Piaceae)? Agricultural and Forest Entomology 17, 302-308. https://doi.org/10.1111/afe.12108

[31] Willmer, P. (2011) Pollination and Floral Biology. Princeton University Press, Princeton.

[32] Kron, P., Brian, C., Peter, G. and Kevan, G. (2001) Across- and Along-Row Pollen Dispersal in High-Density Apple Orchards: Insights from Allozyme Markers. The Journal of Horticultural Science and Biotechnology, 76, 286-294. https://doi.org/10.1080/14620316.2001.11511365

[33] Kevan, P.G. and Menzel, R. (2012) The Plight of Pollination and the Interface of Neurobiology, Ecology and Food Security. The Environmentalist, 32, 300-310. https://doi.org/10.1007/s10669-012-9394-5

[34] Knudsen, J.T., Tollsten, L. and Bergström, L.G. (1993) Floral Scents-A Checklist of Volatile Compounds Isolated by Head-Space Techniques. Phytochemistry, 33, 253-280. https://doi.org/10.1016/0031-9422(93)85502-I

[35] Pichersky, E. and Gershenzon, J. (2002) The Formation and Function of Plant Volatiles: Perfumes for Pollinator Attraction and Defense. Current Opinion in Plant Biology, 5, 237-243. https://doi.org/10.1016/S1369-5266(02)00251-0 
[36] Theis, N. (2006) Fragrance of Canada thistle (Cirsium arvense) Attracts Both Floral Herbivores and Pollinators. Journal of Chemical Ecology, 32, 917-927. https://doi.org/10.1007/s10886-006-9051-x

[37] Stubbs, A.E. and Falk, S.J. (1983) British Hoverflies. An Illustrated Identification Guide. British Entomological and Natural History Society.

[38] Landis, D.A., Wratten, S.D. and Gurr, G.M. (2000) Habitat Management to Conserve Natural Enemies of Arthropod Pests in Agriculture. Annual Review of Entomology, 45, 175-201. https://doi.org/10.1146/annurev.ento.45.1.175

[39] Munyuli, T. (2011) Farmers' Perceptions of Pollinators' Importance in Coffee Production in Uganda. Agricultural Sciences, 2, 318-333. https://doi.org/10.4236/as.2011.23043

[40] Munyuli, M.T. (2013) Pollinator Biodiversity in Uganda and in Sub-Sahara Africa: Landscape and Habitat Management Strategies for Its Conservation. International Journal of Biodiversity and Conservation, 3, 551-609.

[41] Wardhaugh, C.W. (2015) How Many Species of Arthropods Visit Flowers? Arthropod-Plant Interactions, 9, 547-565. https://doi.org/10.1007/s11829-015-9398-4

[42] Greenleaf, S.S. and Kremen, C. (2006) Wild Bees Enhance Honey Bees' Pollination of Hybrid Sunflower. Proceedings of the National Academy of Sciences, 103, 13890-13895. https://doi.org/10.1073/pnas.0600929103

[43] Kosior, A., Celary, W., Olejniczak, P., Fijał, J., Król, W., Solarz, W. and Płonka, P. (2007) The Decline of the Bumble Bees and Cuckoo Bees (Hymenoptera: Apidae: Bombini) of Western and Central Europe. Oryx, 41, 79-88.

https://doi.org/10.1017/S0030605307001597

[44] Winfree, R., Williams, N.M., Dushoff, J. and Kremen, C. (2007) Native Bees Provide Insurance against Ongoing Honey Bee Losses. Ecology Letters, 10, 1105-1113.

https://doi.org/10.1111/j.1461-0248.2007.01110.x

[45] Potts, S.G., Biesmeijer, J.C., Kremen, C., Neumann, P., Schweiger, O. and Kunin, W.E. (2010) Global Pollinator Declines: Trends, Impacts and Drivers. Trends in Ecology \& Evolution, 25, 345-353. https://doi.org/10.1016/j.tree.2010.01.007

[46] Klein, A.M., Vaissiere, B.E., Cane, J.H., Steffan-Dewenter, I., Cunningham, S.A., Kremen, C. and Tscharntke, T. (2007) Importance of Pollinators in Changing Landscapes for World Crops. Proceedings of the Royal Society of London B: Biological Sciences, 274, 303-313. https://doi.org/10.1098/rspb.2006.3721

[47] Aouar-Sadli, M., Louadi, K. and Doum, S.E. (2008) Pollination of the Broad Bean (Vicia faba L. var. Major) (Fabaceae) by Wild Bees and Honey Bees (Hymenoptera: Apoidea) and Its Impact on the Seed Production in the Tizi-Ouzou Area (Algeria). African Journal of Agricultural Research, 3, 266-272.

[48] Stein, K., Coulibaly, D., Stenchly, K., Goetze, D., Porembski, S., Lindner, A., Konaté, S. and Linsenmair, E.K. (2017) Bee Pollination Increases Yield Quantity and Quality of Cash Crops in Burkina Faso, West Africa. Scientific Reports, 7, Article No. 17691. https://doi.org/10.1038/s41598-017-17970-2

[49] Bischoff, M., Campbell, D.R., Lord, J.M. and Robertson, A.W. (2013) The Relative Importance of Solitary Bees and Syrphid Flies as Pollinators of Two Outcrossing Plant Species in the New Zealand Alpine. Austral Ecology, 38, 169-176. https://doi.org/10.1111/j.1442-9993.2012.02389.x

[50] Naylor, R. and Ehrlich, P.R. (1997) Natural Pest Control Services and Agriculture. Nature's Services: Societal Dependence on Natural Ecosystems, 151-174.

[51] Aizen, M.A., Garibaldi, L.A., Cunningham, S.A. and Klein, A.M. (2009) How Much 
Does Agriculture Depend on Pollinators? Lessons from Long-Term Trends in Crop Production. Annals of Botany, 103, 1579-1588. https://doi.org/10.1093/aob/mcp076

[52] Garibaldi, L.A., Steffan-Dewenter, I., Kremen, C., Morales, J.M., Bommarco, R., Cunningham, S.A., Carvalheiro, L.G., Chacoff, N.P., Dudenhöffer, J.H., Greenleaf, S.S. and Holzschuh, A. (2011) Stability of Pollination Services Decreases with Isolation from Natural Areas despite Honey Bee Visits. Ecology Letters, 14, 1062-1072. https://doi.org/10.1111/j.1461-0248.2011.01669.x

[53] Ngamo, T.L., Goudoum, A., Ngassoum, M.B., Ngassoum, M., Lognay, G., Malaisse, F. and Hance, T. (2007) Chronic Toxicity of Essential Oils of 3 Local Aromatic Plants towards Sitophilus zeamais Motsch (Coleoptera: Curculionidae). African Journal of Agricultural Research, 2, 164-167.

[54] Mkenda, P.A., Stevenson, P.C., Ndakidemi, P., Farman, D.I. and Belmain, S.R. (2015) Contact and Fumigant Toxicity of Five Pesticidal Plants against Callosobruchus maculatus (Coleoptera: Chrysomelidae) in Stored Cowpea (Vigna unguiculata). International Journal of Tropical Insect Science, 35, 172-184. https://doi.org/10.1017/S174275841500017X

[55] Wulff, R. (1973) Intrapopulational Variation in the Germination of Seeds in Hyptis suaveolens. Ecology, 54, 646-649. https://doi.org/10.2307/1935354

[56] Adda, C., Atachi, P., Hell, K. and Tamò, M. (2011) Potential Use of the Bushmint, Hyptis suaveolens, for the Control of Infestation by the Pink Stalk Borer, Sesamia calamistis on Maize in Southern Benin, West Africa. Journal of Insect Science, 11, 33.

[57] Edeoga, H.O., Omosun, G. and Uche, L.C. (2006) Chemical Composition of Hyptis suaveolens and Ocimum gratissimum Hybrids from Nigeria. African Journal of Biotechnology, 5, 892-895.

[58] Sharma, N. and Tripathi, A. (2008) Integrated Management of Postharvest Fusarium Rot of Gladiolus Corms Using Hot Water, UV-C and Hyptis suaveolens (L.) Poit. Essential Oil. Postharvest Biology and Technology, 47, 246-254. https://doi.org/10.1016/j.postharvbio.2007.07.001

[59] Ndakidemi, P.A. and Dakora, F.D. (2003) Legume Seed Flavonoids and Nitrogenous Metabolites as Signals and Protectants in Early Seedling Development. Functional Plant Biology, 30, 729-745. https://doi.org/10.1071/FP03042

[60] Ofuya, T.I., Olotuah, O. and Akinyoade, D. (2010) The Effect of Storage on the Efficacy of Eugenia Aromatica (Baill.) in the Control of Callosobruchus Maculatus (Fabricius)(Coleoptera: Bruchidae) Pest. Journal of Applied Sciences and Environmental Management, 14, 97-100. https://doi.org/10.4314/jasem.v14i1.56509

[61] Chi, M.V. and Apiah, S.P. (2012) Toxic and Feeding Deterrent Effects of Hyptis suaveolens and Hyptis spicigera Extracts on Cowpea Weavils (Callosobruchus maculatus). Canadian Journal of Pure and Applied Sciences, 6, 1967-1972.

[62] Aluri, R.J. (1992) Natural Pollination and Fruiting Limitation in Hyptis suaveolens as a Function of Predation of Lynx Spider on Pollinators and Florivory by Katydid. Proceedings-Indian National Science Academy Part B, 58, 201.

[63] Rani, B.U. and Raju, A.S. (2016) A Study on Butterfly-Flower Interactions. Journal of Palynology, 52, 111-131.

[64] Pandey, A.K., Singh, P. and Tripathi, N.N. (2014) Chemistry and Bioactivities of Essential Oils of Some Ocimum Species: An Overview. Asian Pacific Journal of Tropical Biomedicine, 4, 682-694. https://doi.org/10.12980/APJTB.4.2014C77

[65] Chowdhury, T., Mandal, A., Roy, S.C. and De Sarker, D. (2017) Diversity of the 
Genus Ocimum (Lamiaceae) through Morpho-Molecular (RAPD) and Chemical (GC-MS) Analysis. Journal of Genetic Engineering and Biotechnology, 15, 275-286. https://doi.org/10.1016/j.jgeb.2016.12.004

[66] Chogo, J.B. and Crank, G. (1981) Chemical Composition and Biological Activity of the Tanzanian Plant Ocimum Suave. Journal of Natural Products, 44, 308-311. https://doi.org/10.1021/np50015a012

[67] Obeng-Ofori, D., Jembere, B., Hassanali, A. and Reichmuth, C. (2000) Effectiveness of Plant Oils and Essential Oil of Ocimum Plant Species for Protection of Stored Grains against Damage by Stored Product Beetles. Proceedings of the 7 th International Working Conference on Stored-Product Protection, Beijing, 799-808.

[68] Gülçin, İ. (2011) Antioxidant Activity of Eugenol: A Structure-Activity Relationship Study. Journal of Medicinal Food, 14, 975-985.

https://doi.org/10.1089/jmf.2010.0197

[69] Ojianwuna Ahmed, A.A. and Mahmoud, A.A. (1997) Carvotacetone Derivatives from the Egyptian Plant Sphaeranthus suaveolens. Phytochemistry, 45, 533-535. https://doi.org/10.1016/S0031-9422(96)00840-0

[70] Obeng-Ofori, D. and Reichmuth, C.H. (1997) Bioactivity of Eugenol, a Major Component of Essential Oil of Ocimum Suave (Wild.) against Four Species of Stored-Product Coleoptera. International Journal of Pest Management, 43, 89-94. https://doi.org/10.1080/096708797229040

[71] Smith, A.H. and Liburd, O.E. (2012) Intercropping, Crop Diversity and Pest Management. University of Florida, IFAS Extension, ENY862, 1-7.

[72] Ruas, P.M., Bonifacio, A., Ruas, C.F., Fairbanks, D.J. and Andersen, W.R. (1999) Genetic Relationship among 19 Accessions of Six Species of Chenopodium L., by Random Amplified Polymorphic DNA Fragments (RAPD). Euphytica, 105, 25-32. https://doi.org/10.1023/A:1003480414735

[73] Salimena, J.P., Monteiro, F.P., de Souza, P.E. and de Souza, J.T. (2015) Extraction of Essential Oil from Inflorescences of Dysphania ambrosioides and Its Activity against Botrytis cinerea. Journal of Medicinal Plants Research, 9, 1006-1012. https://doi.org/10.5897/JMPR2015.5743

[74] Wohlenberg, V.C. and Lopes-da-Silva, M. (2009) Effect of Chenopodium ambrosioides L. (Chenopodiaceae) Aqueous Extract on Reproduction and Life Span of Drosophila Melanogaster (Meigen)(Diptera: Drosophilidae). Bioscience Journal, 25, 129-132.

[75] Mwanauta, R.W., Mtei, K.A. and Ndakidemi, P.A. (2014) Prospective Bioactive Compounds from Vernonia amygdalina, Lippia javanica, Dysphania ambrosioides and Tithonia diversifolia in Controlling Legume Insect Pests. Agricultural Sciences, 5, 1129-1139. https://doi.org/10.4236/as.2014.512123

[76] Barbosa, F.S., Leite, G.L.D., Alves, S.M., Nascimento, A.F., D’Ávila, V.D.A. and Costa, C.A.D. (2011) Insecticide Effects of Ruta graveolens, Copaifera langsdorffii and Chenopodium ambrosioides against Pests and Natural Enemies in Commercial Tomato Plantation. Acta Scientiarum: Agronomy, 33, 37-43.

[77] Dembitsky, V., Shkrob, I. and Hanus, L.O. (2008) Ascaridole and Related Peroxides from the Genus Chenopodium. Biomedical Papers of the Medical Faculty of Palacky University in Olomouc, 152, 209-215. https://doi.org/10.5507/bp.2008.032

[78] Vázquez-Covarrubias, D.A., Jiménez-Pérez, A., Castrejón-Ayala, F., Figueroa-Brito, R. and Belmont, R.M. (2015) Effects of Five Species of Chenopodiaceae on the Development and Reproductive Potential of Copitarsia decolora (Lepidoptera: Noctuidae). Florida Entomologist, 98, 80-85. https://doi.org/10.1653/024.098.0114 
[79] Suarez-Vargas, A.D., Bautista-Martinez, N., Valdez-Carrasco, J., Angulo-Ormeno, A., Alatorre-Rosas, R., Vera-Graziano, J., Equihua-Martinez, A. and Manuel-Pinto, V. (2006) Population Fluctuation of Copitarsia decolora (Guenee) and Its Association with Comercial Crucifers. Agrociencia, 40, 501-509.

[80] Chiasson, H., Vincent, C. and Bostanian, N.J. (2004) Insecticidal Properties of a Chenopodium-Based Botanical. Journal of Economic Entomology, 97, 1378-1383. https://doi.org/10.1093/jee/97.4.1378

[81] Denloye, A., Makanjuola, W., Teslim, O., Alafia, O., Kasali, A. and Eshilokun, A. (2010) Toxicity of Chenopodium ambrosioides L. (Chenopodiaceae) Products from Nigeria against Three Storage Insects. Journal of Plant Protection Research, 50, 379-384. https://doi.org/10.2478/v10045-010-0064-7 